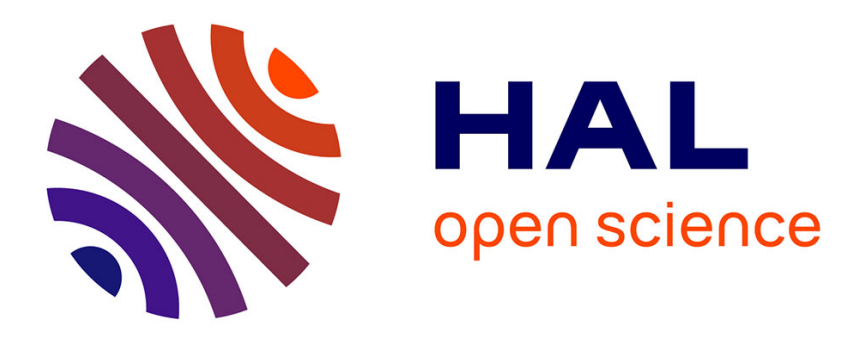

\title{
The Point of Banter in the television show Pointless
}

Linda Pilliere

\section{To cite this version:}

Linda Pilliere. The Point of Banter in the television show Pointless. Manuel Jobert; Sandrine Sorilin. The Pramatics of Irony and Banter, Chapter 8, John Benjamins, pp.141-164, 2018, 9789027200532. 10.1075/lal.30.08pil . hal-01995853

\section{HAL Id: hal-01995853 https://hal-amu.archives-ouvertes.fr/hal-01995853}

Submitted on 24 Mar 2019

HAL is a multi-disciplinary open access archive for the deposit and dissemination of scientific research documents, whether they are published or not. The documents may come from teaching and research institutions in France or abroad, or from public or private research centers.
L'archive ouverte pluridisciplinaire HAL, est destinée au dépôt et à la diffusion de documents scientifiques de niveau recherche, publiés ou non, émanant des établissements d'enseignement et de recherche français ou étrangers, des laboratoires publics ou privés. 


\title{
Author accepted manuscript ${ }^{1}$
}

Chapter published in: The Pragmatics of Irony and Banter, edited by Manuel Jobert and Sandrine Sorlin John Benjamins, (Linguistic Approaches to Literature 30) 2018, pp. 141-164. https://doi.org/10.1075/lal.30.08pil

Linda Pillière, Aix Marseille Univ, LERMA, Aix-en-Provence, France The Point of Banter in the Television Show Pointless

\begin{abstract}
This paper explores banter within the television quiz show Pointless. Building on previous theories of banter, I suggest that the composite nature of the phenomenon can usefully be analysed within an interactional pragmatic model, such as that proposed by Lecercle (1999). Using this model to analyse various episodes of Pointless, I seek to demonstrate that banter is created within a dynamic interpersonal process. I focus on the sequential interaction between speaker and the various hearers involved in the exchange, as opposed to isolated utterances. I propose that any analysis of banter needs not only to study the linguistic aspects of a series of utterances, but also the sociocultural context and the encyclopaedic knowledge that each participant brings to the exchange.
\end{abstract}

\footnotetext{
${ }^{1}$ Under copyright. The publisher should be contacted for permission to re-use or reprint the material in any form
} 
Keywords: speaker, hearer, mock impoliteness, banter, Pointless

\section{Introduction}

The BBC quiz show, Pointless, owes part of its success to the banter between the two hosts - Alexander Armstrong who asks the questions and Richard Osman who explains the answers. Initially edited out from the first two series, the chat and banter were left in from series three onwards at the request of Armstrong, who felt that without it "all you were left with was a sort of terribly inept game show". ${ }^{i}$ Recognised by journalists and the public alike, the show's banter provides a rich source of examples for study, even if a TV dialogue is not as natural as everyday conversation. Moreover, Pointless has run for over seven years and reached a thousand episodes, making it possible to analyse the banter as a dynamic evolving process, a sequence of turntaking, rather than isolated exchanges, as was the case in early studies on politeness and impoliteness. The different episodes can also be contrasted and compared, making it easier to pinpoint any recurring forms that will help us identify banter.

After examining existing theories on banter and how they relate to mock impoliteness, I will suggest that these theories may be integrated within a pragmatic model of interpretation. The second part will test and expand this 
theoretical approach through a microanalysis of the banter in several episodes from Pointless. ${ }^{\text {ii }}$

\section{What is banter?}

The term banter probably owes its origins to seventeenth century London slang. The Oxford English Dictionary defines the verb as meaning "to make fun of (a person); to hold up to ridicule (...). Now usually of good-humoured raillery". However, the noun is defined as: "wanton nonsense talked in ridicule of a subject or person", underlining that the object of banter need not necessarily be a person. The Chambers $21^{\text {st }}$ Dictionary goes further, defining the noun as "light-hearted friendly talk" and the verb as "to tease someone or joke". iii Some analyses of banter which situate it within a "jocular frame" are closer to the Chambers definition (cf. Dynel 2008: 246).

The British English meaning of banter has varied over time and has recently become associated with offensive, inappropriate joking, even bullying. ${ }^{\text {iv }}$ Various cases brought before employment tribunals have revealed the thin line that exists between banter in the workplace and verbal harassment. Scholars have therefore used different terms to distinguish between these serious meanings: jocular mockery and jocular abuse (Haugh and Bousfield 2012), teasing and put-down humour (Dynel 2008), or aggressive and affiliative humour (Martin et al. 2003). For Boxer and Cortés-Conde, teasing 
functions "on a continuum that ranges from bonding to nipping to biting" (1997: 276).

While some analyses have examined this dual nature of banter in relation to the speaker's intention, others underline the important role played by the reaction of the hearer and/or the presence of a third party (Dynel 2008). A jocular remark made to amuse a third party at the hearer's expense is one way of identifying put-down humour or aggressive teasing (Dynel 2008: 248). Banter can therefore refer both to good-humoured mockery, even jocular talk, but also to unpleasant taunting, thereby underlining the role played by interpretation in identifying the phenomenon, and the need to establish a theoretical framework that considers all the participants within the process itself, not just the speaker.

\section{Banter: the theories so far}

The starting place for the analysis of banter has invariably been existing theories of politeness and impoliteness, especially Leech's politeness model (1983) and Brown and Levinson's politeness strategies (1987).

Building on Goffman's theory of face, "the positive social value a person effectively claims for himself by the line others assume he has taken during a particular contact" (Goffman 1967: 5), Brown and Levinson elaborated a theoretical framework that presented politeness as a means of saving face or 
reducing potentially face-threatening acts (FTAs). This led Culpeper (1996) to posit that similar impoliteness strategies also occur. Impoliteness is the result of interaction between speaker and hearer and occurs when "(1) the speaker communicates face-attack intentionally, or (2) the hearer perceives and/or constructs behaviour as intentionally face-attacking, or a combination of (1) and (2)" (Culpeper 2005: 38).

However, neither politeness nor impoliteness need necessarily be genuine. Leech's model of politeness includes what he calls "second-order principles" (1983: 144-5), namely irony and banter, both of which feature forms that on the surface appear to be polite or impolite. When a speaker is ironic, s/he appears to be making a friendly inoffensive remark, yet they are in fact being impolite and therefore distancing themselves from their hearer. The use of banter, on the other hand, allows the speaker to say something which is offensive in jest. Leech concludes that the irony principle is a manifestation of mock politeness, while the banter principle belongs to the category of mock impoliteness. Thus, genuine impoliteness is hostile and aggressive, whereas mock impoliteness is "impoliteness that remains on the surface, since it is understood that it is not intended to cause offence" (Culpeper 1996: 352). Leech also argues that banter involves saying something that is false: "What $s$ says is impolite to $h$ and is clearly untrue. Therefore, what $s$ really means is polite to $h$ and true" (Leech 1983: 144). Consequently, both irony and banter flout one of Grice's conversational maxims, the Maxim of Quality (1975): "Do not say what you believe to be false". 
However, the idea that banter, or more generally mock impoliteness, necessarily involves an untruth has been questioned (Haugh and Bousfield 2012; Mills 2003; Nowik 2005). Mock impoliteness “might actually be used, precisely because there is an element of truth in the utterance" (Mills 2003: 123) and banter, far from focussing on some fictive element, may refer to an existing "trait, habit, or characteristic of the recipient of the banter" (Plester and Sayers 2007: 159). This leads scholars such as Nowik to posit that Leech's first condition "say something that is obviously untrue" should therefore be changed to "say something that (...) is obviously not serious" (2008: 108). However, experimental research by Vergis (2015) suggests inferences derived from flouting the Maxim of Quality are indeed robust, even if other factors such as the speaker's emotional state and face concerns also play a role (personal communication).

Saying something ostensibly offensive, in the knowledge that the hearer will not take offence, implies a close rapport between speaker and hearer. For Slugoski and Turnbull (1988), the relationship affect is all important in banter: it allows the hearer to interpret a counter-to-fact insult as a compliment. Contrary to irony, banter can therefore be "a signal of solidarity and camaraderie" (Leech 2014: 239) indicating a close relationship with the hearer; it is a means of "establishing or maintaining a bond of familiarity" (Leech 1983: 144), and its intention is "to create and reinforce relationship through social acceptance-friendship strategies" (Plester and Sayers 2007: 5). Culpeper describes banter as "mock impoliteness for social harmony" (1996: 
352), an idea expounded upon by Kisielewska-Krysiuk (2010) in her study on banter and phatic communication. She argues that the main role of both is to maintain social and interpersonal communication rather than impart information.

More recently, Haugh and Bousfield (2012) and Haugh (2015) suggest that rather than examining mock impoliteness within politeness/impoliteness theories, it is necessary to distinguish between mock impoliteness as an evaluation, and social actions, which include teasing, mockery and banter. They define mock impoliteness as "evaluations of talk or conduct that are potentially open to evaluation as impolite by at least one of the participants in an interaction, and/or as non-impolite by at least two participants" (2012: 1103). The notion of "potentially open to evaluation" underlines again the important role played by interpretation, although I would suggest that it is not simply a case of evaluating a remark as being non-impolite, as the hearer may decide not to accept a remark as banter despite evaluating it as such. This possibility has often been neglected (Bousfield 2008: 132-3), but is fully integrated into Lecercle's model.

All the approaches studied so far underline the importance of interpersonal relations, with a growing awareness among scholars that interpretation is an important factor in the identification of banter. The need to write contextual and co-textual factors into the equation has also been acknowledged (see Culpeper 2011 for a detailed analysis of this). 
This leads me to suggest that these various theories are, in many ways, consistent with an interactional pragmatic framework, one which considers speaker, hearer, the linguistic strategies involved, and the context.

\section{Banter within an interactional pragmatic framework}

The model I wish to use is that proposed by Lecercle (1999), itself a reformulation of Butler's theory of subjection and subjectivity (1997). My aim is not to reject traditional approaches to banter but to explore whether they can be integrated into this more general framework of interactional pragmatics.

Lecercle considers that there are five actants in a situation of communication: a speaker (A), a hearer (R), a message (T), an encyclopaedia (E) and language (L). It should be noted that Lecercle is mainly concerned with written texts and he therefore uses the terms author, reader, and text for speaker, hearer, and message, respectively. In diagram form, this gives us (Lecercle 1999: 75):

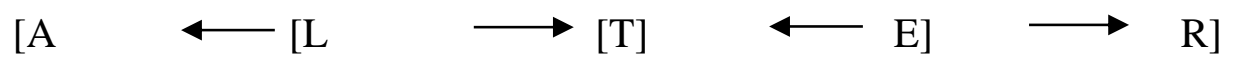

In the centre is the text $(\mathrm{T})$ or message, the most important element in the process. It is produced by language (L) and the encyclopaedia (E). The term encyclopaedia is borrowed from Umberto Eco and refers to social 
institutions, shared knowledge and beliefs. It is therefore a mental model, an accumulation of experience which enables us to form a situation model (van Dijk and Kintsch 1983: 12). As such, it is a dynamic construct, capable of changing and developing as each new experience is added and assimilated. The author/speaker (A) and the reader/hearer (R) are effects of $(\mathrm{T})$, as indicated by the outward pointing arrows. The square brackets show that neither reader/hearer nor author/speaker entertains a direct relationship with the text, but each is "filtered" by language and the encyclopaedia, so that neither controls meaning. While previous research has presented the discourse level of banter as a one-way process with an arrow going from speaker to hearer (Bousfield 2007), Lecercle's presentation allows for indirection, whereby the meaning of the text is separated from the author's meaning (thus allowing for misinterpretation) and varies with the conjuncture.

Both speaker and hearer are places within a structure, occupied by different subjects at different moments, hence the term actant, borrowed from Greimas, to refer to all five sites in the diagram.

To demonstrate how this model works in practice, and how it can integrate existing theories, I will use an extract from the beginning of an episode of Pointless. Armstrong is inviting the couples to introduce themselves by name and to say where they are from. I should perhaps point out that before Pointless Armstrong was best known for being one half of a comedy duo, “Armstrong and Miller", which first aired on television in 1997. As we will 
see in subsequent extracts, Osman constantly states that Miller is the more talented of the two and that another comedy duo, Mitchell and Webb, are funnier than either of them.

\section{Example 1}

1 ARMSTRONG: And couple number four?

2 BLAKE: My name's Joshua Blake, this is my friend Jamie Laden - my legal advisor, carer and all-round good guy and we go to the University of Nottingham.

4 ARMSTRONG: And these are today's contestants.

5

6

7

8 OSMAN:

9 OSMAN:

10 ARMSTRONG:

11 OSMAN: $\quad$....that we've got a character on the show?

12 ARMSTRONG: Yes, I spotted that.

13 OSMAN: Did you notice that?

14 ARMSTRONG: I spotted that three-fold, all at once.

15 OSMAN: Did you? What was the clue?

16 ARMSTRONG: It was when Suzanne said that...

17 OSMAN: $\quad$ No it was Blake...

18 ARMSTRONG: ...who's actually called Joshua Blake. So, already

9 OSMAN: He's got a surname for a name.

20 ARMSTRONG: Yeah, literally his surname is the name he's gone for on his badge and he's wearing a hat.

24 OSMAN: It was very good, very strong. A lot to live up to the rest of the show.

25 ARMSTRONG: Yeah.

26 OSMAN: Wouldn't want to be Blake/Joshua right about now. 
That's a big start.

BLAKE: I'm sensing a bit of jealousy here. and there's no denying it. The career starts here.

34 ARMSTRONG: Yeah.

35 OSMAN: I will give them that.

36 BLAKE: $\quad$ But we've also got the looks instead as well.

37 OSMAN: It's going terrifically well, isn't it?

38 ARMSTRONG: I don't...

Er, yes, it is going well.

Series 10 episode 17

Both speaker and hearer are interpellated, a term Lecercle borrows from Althusser, or assigned a place (1999: 152ff). In this extract, Joshua (R) is interpellated, captured at a place by language (L). By saying "Couple number four", Armstrong names and identifies Blake and his partner (R) as contestants. He does so through an utterance (T) which is filtered through language (L) (he chooses the appropriate term for addressing the two) in accordance with his understanding of the context (E) (a quiz show). At the same time, Armstrong is himself interpellated through language and assigned the place of host. "Positioned as both addressed and addressing, [...] the subject is not only founded by the other, requiring an address in order to be, but its power is derived from the structure of address as both linguistic vulnerability and exercise" (Butler 1997: 30).

Joshua, however, refuses the position he is ascribed. As Lecercle points out, counter-interpellation is always a possibility. ${ }^{\mathrm{v}}$ The representation that Joshua 
has of himself does not match the one constructed by Armstrong. Instead of giving the expected reply, Joshua first presents Jamie as "his legal advisor, carer and all-round good guy" (3), and only incidentally does he mention that he and his partner go to the University of Nottingham. Grice's conversational maxims (1975) can be integrated here. By giving too much information about himself and his team member, Joshua flouts the Maxim of Quantity. But he also flouts the Maxim of Quality, as the relationship he describes between himself and Jamie cannot be true: the various professions enumerated are almost mutually exclusive. Not only does Joshua refuse the representation that Armstrong initially has of him as a contestant, he interpellates Armstrong in turn, usurping Armstrong's role and mimicking him by introducing Jamie in terms that echo Armstrong's typical introduction of Osman at the start of every show. Joshua's behaviour can be evaluated as impolite here, as it contains a threat to Armstrong's Social Identity face, ${ }^{\mathrm{vi}}$ the representation that Armstrong has of his social role (Spencer-Oatey 2000). However, the studio audience's laughter and Osman and Armstrong's smiles signal that this FTA is not to be taken seriously. Filtered through language (L) (the flouting of Grice's maxims) and the encyclopaedia (the type of quiz show etc.), Joshua's utterance (T) is evaluated as jocular mockery (Haugh 2010). ${ }^{\text {vii }}$

Consequently, Osman and Armstrong have to adjust their representation of Joshua (he is clearly no ordinary contestant). They proceed with an attack on Joshua's Social Identity face, mocking his name and attire (20-2). 
Their FTA is strengthened by Joshua being the object of their discourse, the third party, or unaddressed ratified hearer (Dynel 2010b). However, filtered through language (L) and the encyclopaedia (E), the remarks cannot be taken at face value. The reference to Joshua's attire remains impersonal. No pejorative adjectives are used; there is nothing in the vein of "Did you see that ridiculous hat he's wearing?" The implicature is not that Joshua has no dress sense or looks ridiculous, but that he has chosen to stand out from the crowd, that he is a "character". Moreover, Armstrong's "I liked his intro" enhances Joshua's positive face. The FTAs are therefore not to be taken seriously and instead of impoliteness we have banter. ${ }^{\text {viii }}$

Osman then makes another potential FTA (26), the implicature being that Joshua will not be so confident or so impressive when it comes to answering the questions. As Osman is the quizmaster, and therefore in a position of power, the potential for impoliteness is reinforced (Locher and Bousfield 2008; Culpeper 1996).

Instead of accepting the role he is assigned, that of third party, Blake again reverses the usual host-contestant relationship by speaking when he hasn't been addressed. He then proceeds to banter with the two hosts, drawing on his knowledge (encyclopaedia) of previous subjects of banter, namely Armstrong's comic partnership with Ben Miller (29; 36) and usurping Osman's role, for it is Osman who usually introduces the topic of Armstrong and Miller. Not content with that, Joshua even offers his own FTA by implying that Armstrong and Miller are not good-looking (36). 
From the above, we can conclude that FTAs arise when there is a difference either between the speaker's representation of the hearer $(R)$ and the hearer's representation of themselves or between the hearer's representation of the speaker (A) and the speaker's representation of themselves. However, if either the speaker or hearer accept the other's representation then the FTA is mitigated.

Banter is thus created as the exchange between speaker and hearer progresses; the relationship between speaker and hearer is a dynamic process and may affect the interpretation of the message (Fisher and Adams 1994: 18).

Having examined how Lecercle's model may work in practice, I wish now to examine the various actants in more detail, in order to identify how banter works in Pointless.

\section{Banter and Pointless}

Initially launched on BBC 2 in 2009, the increasingly popular quiz show Pointless is now followed by an average of 3.6 million viewers on its daily evening slot on BBC 1. There is even a spin-off, Pointless Celebrities, broadcast every Saturday evening during prime time. Each episode involves four pairs of contestants who must give a correct answer while scoring as few points as possible. Before the show, the questions are given to a panel of one hundred people who have one hundred seconds to find as many answers as 
possible. The contestants' score corresponds to the number of people on the panel who have given the same answer. A pointless answer is one that no member of the panel thought of, and adds $£ 250$ to the jackpot. In the final round, a pointless answer wins the jackpot.

\section{The actants in the process of banter}

\subsection{Interaction between speaker(s) and hearer $(s)$}

As stated above, banter is often considered to take place between intimates (Culpeper 2011: 209). Friends since Cambridge, Armstrong and Osman act out their friendship on screen. Armstrong always introduces Osman as "my pointless friend", and the two exchange remarks during the show on personal details and preferences, revealing that they know several facts about each other's lives. Furthermore, they frequently indulge in a form of humorous verbal exchange or conjoint humour (Holmes 2006) which has nothing to do with the questions, thus creating an image of two people who enjoy a good rapport based on shared knowledge and experience or, encyclopaedia. This collaborative humour can lead to the creation of an elaborate fictional situation, or joint fantasizing (Kotthoff 2007), as illustrated by the following episode from series 5. The two competing pairs of contestants (Dee and Colin and Pat and Tony) are asked to name a Sebastian Faulks novel. As neither 
team of contestants can do so, they invent fictive titles: A Day at the Seaside and Murder:

\section{Example 2}

1 ARMSTRONG: A Day at the Seaside and Murder (Laughter) Oh Kay.

6 PAT:

7 TONY:

8 ARMSTRONG:

9 OSMAN: Yeah. Poor old Sebastian Faulks, sitting at home, with a nice cup of tea, thinking, "Ah I like Pointless."

10 ARMSTRONG: I'll tell you what I'll have a little break from my new, what is it... my seventh novel

11 OSMAN: Eleventh novel

12 ARMSTRONG: Eleventh novel! I'll just settle down and watch a little bit of Pointless.

13 OSMAN: The whole family are sort of upstairs doing things ... and he says "Everyone - Everyone." Presses pause.

14 ARMSTRONG: Quick! Quick! It's me on Pointless.

15 OSMAN: They're doing me on Pointless! They're doing me on Pointless. They're gonna guess my novels. I wonder what they're gonna say. Which of my novels do they like the best, I wonder?

19 ARMSTRONG: Mmm... maybe..

20 OSMAN: The whole family coming down the stairs (imitates noise and movement with hands). What is it Dad? What is it Dad?

21 ARMSTRONG: What is it? What is it?

22 OSMAN: They're doing me on Pointless!

23 ARMSTRONG: You're on Pointless today! Quick! Dad's on Pointless! 


$\begin{array}{lll}24 & \text { OSMAN: } & \text { Quick! } \\ 25 & \text { ARMSTRONG: } & \text { Quick! } \\ 26 & \text { OSMAN: } & \text { Fifteen of the Faulks clan now all sitting on sofas. } \\ 27 & & \text { He's just pressing un-pause there. He's on live } \\ & & \text { replay. } \\ 28 & \text { ARMSTRONG: } & \text { OK } \\ 29 & \text { OSMAN: } & \text { Everybody. Right, everyone now, absolute quiet. } \\ 30 & & \text { Ssh! Dim the lights! Pull the curtains, dim the } \\ & & \text { lights. } \\ 31 & & \text { 'Cause there's a reflection on the screen } \\ 32 & \text { ARMSTRONG: } & \text { No, quickly! Ring everyone we know!" } \\ 33 & \text { OSMAN : } & \text { There's a reflection on the screen. I can't see Tony. } \\ 34 & & \text { I can't see Tony's face when he's going to say my } \\ & & \text { novel. (Pause) } \\ 35 & & \text { And then ... look what you did! } \\ 36 & \text { COLIN: } & \text { Rub it in a bit more! } \\ 37 & \text { TONY: } & \text { I thought he played for Man United! } \\ 38 & \text { COLIN: } & \text { Midfielder, yeah. He's good. } \\ 39 & \text { OSMAN: } & \text { That's not helping! You're thinking of Sebastian } \\ & & \text { Veron! }\end{array}$

\section{Series 5 Episode 57}

For this exchange to be fast and funny, both speaker and hearer need to understand how each other's mind works. By correctly representing each other's language and encyclopaedia, they can quickly elaborate on what the other has just said, taking turns to pretend they are part of Faulks family (23) or Faulks himself (22). The end of the sequence is signalled by Osman's And then look what you did (35), which is significantly slower with each word accentuated, thus contrasting with the previous fast pace and animated exchange.

This conjoint humour will form part of the audience's encyclopaedia (E) regarding the relationship between the hosts, and subsequent text $(\mathrm{T})$ will be filtered through this, influencing how potentially impolite remarks are interpreted. 
Should this exchange be labelled banter? It certainly corresponds to Norrick's rather broad definition of banter as a "rapid exchange of humorous lines oriented towards a common theme, though aimed primarily at mutual entertainment rather than topical talk" (1993: 29) or Dynel's “match of verbal ping-pong played by two (or more) interlocutors within a jocular mode" (2008: 243-4). For one viewer, there is no doubt: "Ah the Sebastian Faulks round, the day I realised just how much I loved and enjoyed Richard and Xander's banter." ${ }^{\text {ix }}$ This episode also closely resembles others to be found on the BBC website under the heading "banter", ${ }^{\mathrm{x}}$ where the humour is not directed at someone, but is centred on a topic, thus diminishing any likelihood of an FTA.

Nevertheless, in example (2), the humour can arguably be evaluated as impolite because it threatens the contestants' Social Identity face. Faulk's imagined disappointment is the direct result of their ignorance (35). Yet, the implicit ridicule is directed less at the contestants' errors or ignorance than at the imagined anti-climax experienced by Sebastian Faulk. The jocular frame (Haugh 2010) enables the contestants to join in the banter: they wave to the imaginary Faulks family watching the programme and even pretend further ignorance by identifying Faulks as a football player (37). The good-natured humour is in sharp contrast with Anne Robinson's more aggressive tactics (Culpeper 2005), and will be re-examined later.

\subsection{From dyadic relations to multiple participants}


In example (2), multiple participants are involved (Dynel 2011b). As Goffman states: "when a word is spoken, all those who happen to be in perceptual range of the event will have some sort of participation status relative to it" (1981: 3). There are various kinds of possible hearers: eavesdroppers who overhear; ratified participants who are not addressed by the speaker; and finally, ratified participants who are indeed addressed by the speaker and who are expected to reply in some way (Goffman 1981: 9). In my examples, no exchange is ever simply between Armstrong and Osman, as the contestants, the studio audience, and the TV viewer are also being addressed. This is quite clear in the way both Armstrong and Osman directly address the cameras and the way the cameras also move towards the studio audience to show them laughing. Significantly, in the first two series, where the banter was edited out, the cameras were fixed and did not move, so that the jokes were missed as the camera was not necessarily on the right person. Once the cameras were trained on all the participants, the result was radically different, and it was possible to focus on the source of the banter and the hearer's reactions.$^{\mathrm{xi}}$ Lecercle's choice of the term actant underlines that the hearer's place is a "role", not a specific person, thus allowing multiple levels of speakers and hearers to be included, with the speaker interpellating the hearer and inherently ratifying the hearer (Dynel 2012: 169-170).

In Pointless, the studio audience rarely replies verbally, even though Osman may address them directly. However, they are ratified to react and their 
audible laughter, their endorsement of the banter, is also communicated visually when the camera switches to focus on them, so that arguably a different role can be identified for the studio audience, that of recipient: ratified hearers who are not conversationalists (Dynel 2011a).

Example (3) illustrates the dynamic role played by the studio audience within the participation framework, potentially influencing how the television viewer may interpret an utterance:

\section{Example 3}

1 ARMSTRONG: Alan. Now then, tell me a little bit... Before I ask Alan anything, Alan said to me before the show, he just said in his Liverpudlian accent, he just said "I know where you live, so no funny stuff."

3 OSMAN: Did he really?

4 ARMSTRONG: Yeah!

5 STUDIO AUDIENCE: Laughter

6 OSMAN: That's cos I gave him your address.

7 STUDIO AUDIENCE: Laughter

8 ARMSTRONG: Ah.

9 OSMAN: But you're not known for funny stuff, are you?

10 STUDIO AUDIENCE and ARMSTRONG: Laughter

11 ARMSTRONG: No!

12 OSMAN to Alan: You're thinking of Ben Miller.

13 STUDIO AUDIENCE: Laughter

14 ALAN: That's the one.

15 He's good.

16 OSMAN: Oh, he is ...he's... Do you know what?

17 That Death In Paradise he does is terrific.

18 It's really good. It's like a weight has been lifted from him (pause) seeing him on that show.

19 STUDIO AUDIENCE and ARMSTRONG: Laughter

20 OSMAN But you realise the brake that's been put on him for so many years.

21 STUDIO AUDIENCE: Laughter. Aw!

22 ARMSTRONG: Oh that's the first time I've ever had sympathy. Oh, Richard.

23 STUDIO AUDIENCE and ARMSTRONG: Laughter 
24 OSMAN: One day I'll push it too far.

25 No, you're OK. You're OK.

26 STUDIO AUDIENCE and ARMSTRONG: Laughter

27 OSMAN: But, but, he is better, he is better.

28 STUDIO AUDIENCE: Laughter

Series 9, Episode 16.

In this example, the exchange between Armstrong and Osman also includes participation from a contestant, Alan. Armstrong mentions that Alan "knows where he lives", the implicature being that Armstrong's life and safety will be in danger should he make one false move. By referring to Alan's Liverpudlian accent, by suggesting that it indicates Alan's belonging to some kind of criminal lowlife and is also socially undesirable, Armstrong makes a potential FTA on Alan's Social Identity face. The FTA is strengthened by the fact that Armstrong, with his RP accent and private-school education, belongs to the dominant social class, and is therefore in a position of power (Culpeper 2008: 39). Armstrong's representation of Alan interpellates Alan into a place that is probably not one that Alan would desire, and so can be considered an FTA. However, Alan's gangster-style threat is exaggerated and out of keeping with the given frame of a family quiz show. It does not correspond to the audience's encyclopaedia, and the exaggeration creates a jocular frame. Moreover, unlike Anne Robinson on The Weakest Link, who contemptuously mimics the contestants' accents (Culpeper 2011: 176), Armstrong, a firstclass mimic, does not actually caricaturise Alan's accent. Finally, Alan's reaction is to laugh, thereby indicating he never intended any threat and that he is not offended either. 
Osman then uses the phrase "no funny stuff" in its literal meaning (9), to start his running joke about Armstrong's comedy partner, Ben Miller, being the more talented of the two. He starts with a closed question (9), a direct address to Armstrong with the use of the second person pronoun, and instead of saying he personally prefers Miller, he uses the passive voice implying this is a shared opinion. The closed question prevents Armstrong from controlling the discourse: the required response is “no". Unlike Osman's previous banter, this opening line is bald-on-record impoliteness (Culpeper 2011), but can also be interpreted as banter based on what we know of previous exchanges and the hearer(s) reactions. Osman then proceeds to exclude Armstrong from the speaker-hearer relationship by addressing the contestant (12). Finally, Osman uses off-record impoliteness: the damage to Armstrong's face is performed through a series of implicatures so that even if Osman's intention is clear, it can be denied (Culpeper 2011). Firstly, Osman praises Miller (16), the implicature being that he is the truly comic partner. Then he talks about a weight having been lifted (18) and a brake removed since Miller went solo (18; 20), the implicature being that Armstrong was the weight and brake. Osman's remarks generate not only laughter from the audience but also a sympathetic "aw". The banter this time is close to being too antagonistic, a fact that Osman himself recognises (24). The dynamic role of the studio audience is enhanced by the camera moving to focus on them $(19 ; 26)$ and arguably, if the audience were not shown and heard laughing, this would be a case of putdown humour as opposed to banter. As Holmes and Schnurr 
remark, "perhaps we can never be totally confident about the ascription of politeness or impoliteness to particular utterances" (2005: 122). Whether the hearer (in this case Armstrong) accepts the speaker's representation of him, will influence how the studio audience and television viewer view the exchange and whether they label it as banter or not.

\subsection{Reacting to banter}

In example (4), Osman draws a parallel between Hans Christian Andersen and Armstrong, through their similar reaction to bad reviews. He uses the same terms: "sobbing uncontrollably" $(4 ; 7)$. Anderson outstayed his welcome at Dickens' (3) and the implicature of "literally a month later you're still there" (7) is that Armstrong was no longer welcome at Osman's. Osman indicates that Armstrong's reviews contrast unfavourably with those of his partner and that even Armstrong's appearance was criticised (12-3). All these remarks, which attack Armstrong's Social Identity face, could be evaluated as impolite.

\section{Example 4}

1 OSMAN: $\quad$ Born in 1805, Hans Christian Andersen.

2 Once went to stay with Charles Dickens and stayed for five weeks

3 Dickens couldn't get rid of him.

4 ARMSTRONG: Oh yes, that's right

5 OSMAN: $\quad$ He used to sob uncontrollably every time he read a review.

6 He's a bit like you. 
Do you remember that ... no, cos do you remember that time you came to my house for tea? And, literally, a month later, you're still there, sobbing uncontrollably at your reviews

9 ARMSTRONG: Crying into the cake.

10 OSMAN: $\quad$ Every single one of them just scathing.

11 ARMSTRONG: Terrible.

12 OSMAN: Some of them were nice about Ben Miller, weren't they?

13 Some of them said Ben is good.

14 But all of them, to a man, just brutal about your

15 ARMSTRONG: It was h.. performance,

16 OSMAN: your appearance. Everything.

17 ARMSTRONG: Oh God, I'm welling up again now, Richard. Get me a cake!

18 Oh no, it's fine. It's fine.

19 OSMAN: I just say, "Thank the Lord for voiceover work!

Series 6 Episode 13

How do Armstrong's reactions inform the audience that this is banter? In example (2), we saw how in conjoint humour both hosts elaborate and echo each other's utterances. In this example, it is a one-way process with Armstrong collaborating, reformulating and therefore agreeing with what Osman says. Osman's sobbing uncontrollably at your reviews (8) is rephrased by Armstrong as crying into the cake (9) and Osman's scathing (10) is reformulated by Armstrong as terrible (11). In this instance, Armstrong accepts Osman's representation of him and Osman's representation of himself by echoing Osman and even topping Osman's remarks. As such, he does not seek to take control of the exchange. Armstrong's replies allow both Osman and the audience as hearer(s), to interpret Armstrong as not being offended. 
As a performance technique, Armstrong's participation here enables him to present himself in a positive light. Being “able to poke fun at one's own foibles, incapabilities and misadventures, the speaker comes over as a quickwitted, and consequently likeable person" (Dynel 2010a: 192). The ability to laugh at oneself is generally recognized as a social attribute, illustrating the British reluctance "to take things too seriously" (Fox 2004: 36). Osman's remarks also allow Armstrong to indulge in self-deprecation, another characteristic of Englishness (Fox 2004: 212). By enabling Armstrong to indulge in self-deprecation and self-mockery, Osman's ostensibly FTA serves to enhance Armstrong's public self-image or positive face, allowing him to present himself as an affable man who does not take himself seriously. How then does Armstrong interpret Osman's remarks as being banter and not face-threatening? This is where the other two actants, language and encyclopaedia, play an important role.

\subsection{Language and Encyclopaedia}

There are arguably no single linguistic forms that are unequivocally proof of banter, although Terkourafi does suggest that "some expressions may be conventionalised to express face-threat" (2008: 67). However, the idea that particular expressions are associated in one's mind with particular contexts resonates with other work, notably Gumperz's notion of contextualisation cues (1982). The preceding examples all have a certain number of linguistic 
forms in common, such as the use of hyperbole and extreme case formulations.

As Leech points out, "hyperbole refers to a case where the speaker's description is stronger than is warranted by the state of affairs described" (1983: 145). In example (4), Osman does not just refer to one single review or one specific critic but to every single one (10) and all of them, to a man (14). Armstrong does not just cry, he sobs uncontrollably. Hyperbole thus flouts Grice's Maxims of Quality and Quantity, since it distorts the truth and provides an excess of information. Extreme case formulations (ECFs) are a subcategory of hyperbole. ${ }^{\text {xii }}$ They also involve overstatement but they are extreme expressions at the far end of the scale (Norrick 2004). In example (2) we find: whole (20), all (26), every (29; 32), and absolute (29). Repetition also creates intensity and provides an excess of information, leading the hearer to suspect that what is being said is not credible. In example (2), exaggeration is created by a movement along a scale, as the imagined scene describes first the individual, Faulks, then the whole family (20), and finally fifteen of the Faulks clan (26). All these linguistic forms signal the flouting of the Maxim of Quantity, and to a lesser extent the Maxim of Quality. ${ }^{\text {xii }}$ Example (5) is a little different as no fictional scene is created. The contestants have been given clues to pairs of people sharing the same name. The contestant, Shalini, has just correctly identified the name of David Mitchell from the clue "Cloud Atlas and Peepshow star" 


\section{Example 5}

1 OSMAN: David Mitchell and Robert Webb - do you ever watch that?

4 ARMSTRONG: I do, yeah

5 OSMAN: Cos you do a double act, don't you?

$6 \quad$ Yours is Armstrong and Miller, is that right?

7 ARMSTRONG: That's ...Yes that's right Richard. Yep ...Yeah

8 OSMAN: $\quad$ No... I'm a... very, very big fan of Mitchell and Webb.

9

You know you've done slightly more (pause) obvious (pause) stuff.

10 But you know what I mean, that slightly toilet humour-y stuff

Actually Ben Miller not so much, but you, very much.

Whereas I think Mitchell and Webb, especially David Mitchell, they're quite clever, they're cleverer

13 ARMSTRONG: Yes, Cerebral. Cerebral.

14 OSMAN: I'm so sorry, this isn't... I'm not quite getting this across right.

Cos they are funnier than you.

16 No. cause they're funnier than you (repeats?) but also cleverer.

18 ARMSTRONG: No I do. I do. I see what you're saying. They're very clever

19 OSMAN: Yeah. They're very clever.

They write a lot of their own stuff as well which I think you and Ben do as well, which I think may be your mistake.

21 AUDIENCE: Laughter

22 ARMSTRONG: Very g (ood). Thanks very much, Richard. Now then, Marti

Series 6 Episode 56

Osman uses the answer to explain why he prefers the comedy act Mitchell and Webb to Armstrong and Miller. However, he rephrases the point in so many ways that his explicit meta-comment, I'm not getting this across right (14) is absurd, and what is a potentially Social Identity FTA (Armstrong is 
not funny) cannot be taken seriously. In terms of linguistic cues (L), it is the over-use of repetition accompanied by heightened intensity that again signals the non-seriousness of his remarks: from quite clever (12) we move to cleverer (12) and very clever (19). Grice's Maxims of Quality and Quantity are both flouted; Quality because Osman's repetition leads us to think his statements are not credible and Quantity because the repetition provides an excess of information and his protestation (14) cannot be believed.

This example also contains non-verbal modalities of communication (Joly and O'Kelly 1989: 32) that are important cues. Osman uses pauses (9) to highlight certain words, thus adding to the hyperbole. Moreover, his tone of voice tends to be deadpan, and this prosodic feature has been recognised as making irony seem less insulting and funnier than a more sarcastic intonation (Martin 2007: 246; Dews and Winner1997: 392). Finally, within the context of the game show, Osman's behaviour here is deviant. Osman's television persona is that of the knowledgeable quizmaster, always fully in possession of the facts. Here, however, he makes an assertion and asks for confirmation (5). He flouts the Maxim of Quality, since he cannot not be in possession of that knowledge, and the question is simply a preface, a means of introducing Armstrong's double act and establishing him as part of a partnership, which is then contrasted unfavourably with Mitchell and Webb. This is then taken a step further as Armstrong is compared unfavourably with his partner Ben Miller. 
Unlike previous examples of collaborative humour, Armstrong responds less with witty repartees than with smiles, a typical non-verbal response to teases (Drew 1987), and with the occasional “yeah”, which encourages Osman to continue. Both visual and verbal clues inform the studio and TV audience that the exchange is not to be taken seriously. The actant "language" in Lercercle's model therefore needs to refer to an inclusive view of language. Following Joly and O'Kelly (1989), I would argue all the various modalities of communication, verbal and non-verbal, need to be included at (L). Body language and prosody, or expressivity, are just as important in constructing meaning, as are lexis and grammar, or expression (see too Culpeper (2011). But the hearer(s) also judge(s) an exchange to be banter through their encyclopaedic knowledge. While earlier studies on politeness and impoliteness focussed on exchanges out of context, to truly understand banter we need to include context within the theoretical framework (see Culpeper 2011). The context is both created by banter but also creates it. In Lecercle's framework, this context is present in the actant E, encyclopaedic knowledge, and can include the notion of norms (Culpeper 2008: 30) and frames (Terkourafi 2001). The examples analysed here contain recurrent features that create situational and co-textual norms. Interpretation of an utterance as being banter, as opposed to impoliteness, depends on the utterance being filtered through the speaker and hearer's sociocultural knowledge. As soon as Osman mentions Ben Miller, Armstrong and the audience guess what will come next. One of the reasons that various contestants can successfully join in the 
mocking of Armstrong as a comic is because this has become an established routine within the programme. There is also the fact that the camaraderie between the two hosts has been established since the beginning of the series. It is therefore unlikely that Osman is seriously criticizing Armstrong's talent as a comic. Moreover, as we saw earlier, Pointless is not exploitative entertainment in the style of The Weakest Link (Culpeper 2005). The nearest Armstrong comes to suggesting a contestant's answer is wide of the mark is an elongated variant of Okay (Oh Kay!) pronounced with a high fall, but there is no sarcasm. Within the frame of a friendly quiz show, any impoliteness is less likely to be taken seriously.

\section{Conclusion}

This study has sought to analyse banter within an interactional pragmatic framework. Although it has been impossible within the space of this chapter to analyse all the assumptions underlying Lecercle's model or to integrate all the existing theories on banter, it has been suggested that Lecercle's model enables us to include a range of theoretical approaches to banter, while at the same time underlining the complexity of the exchange and the necessity of including all five actants, rather than focussing on one to the detriment of the others. It is a framework that enables us to examine banter, and more importantly impoliteness and politeness phenomena, from various places 
within the structure. Lecercle's framework also underlines that interpretation is continually being negotiated, allowing us to account for the idea that neither banter nor face are fixed stable phenomena but constantly evolving and changing as the various elements within the framework change and evolve. Thus, an utterance can be interpreted differently by the various participants in a conversation depending on how they assess the linguistic content, but also in relation to the prosodic and gestural cues, or in relation to their encyclopaedia. Each participant's interpretation will depend on their knowledge of each other and of previous exchanges, and will be negotiated in interaction. The presence of the actant encyclopaedia, which can include much recent research on framing, also enables us to consider cultural scripts. Finally, the more general framework afforded by Lecercle's model allows various possible evaluations of banter including ones that do not sit so neatly within a mock impoliteness analysis. Following Locher (2015), I would argue that a multi-angled approach is a "worthy tradition that should be continued", and a multi-layered approach can account for the complexity of banter.

I would like to thank my anonymous reviewers for their helpful comments. Any errors that remain are, of course, my own.

\section{References}


Bousfield, Derek. 2007. Never a truer word said in jest. A pragmalinguistic analysis of impoliteness as banter in Shakespeare's Henry IV, part I. In Contemporary Stylistics, Marina Lambrou and Peter Stockwell (eds), 209220. London: Continuum.

Bousfield, Derek. 2008. Impoliteness in Interaction. Amsterdam: John Benjamins:

Boxer, Diana, Cortés-Conde, Florencia. 1997. From bonding to biting: conversational Joking and identity display. Journal of Pragmatics 27: 275294.

Brown, Penelope, Levinson, Stephen C. 1987 [1978]. Politeness: Some Universals in Language Usage. Cambridge: Cambridge University Press. Butler, Judith. 1997. Excitable Speech. London: Routledge. Carston, Robyn and Wearing, Catherine. 2015. Hyperbolic language and its relation to metaphor and irony. Journal of Pragmatics 79: 79-92. Culpeper, Jonathan. 1996. Towards an anatomy of impoliteness. Journal of Pragmatics 25: 349-367.

Culpeper, Jonathan. 2005. Impoliteness and entertainment in the television quiz show: “The Weakest Link". Journal of Politeness Research 1: 35-72. Culpeper, Jonathan. 2008. Reflections on impoliteness, relational work and power. In Impoliteness in language: Studies on its interplay with power in theory and practice, Miriam A. Locher, Derek Bousfield,. (eds), 17-44. Berlin and New York: Mouton de Gruyter, Culpeper, Jonathan. 2011. Impoliteness: Using Language to Cause Offence. Cambridge: Cambridge University Press.

Dews Shelly and Winner Ellen. 1997. Attributing Meaning to Deliberately False Utterances. In The Problem of Meaning Behavioural and Cognitive Perspectives, Charlotte Mandell, Allyssa McCabe (eds), 377-414. Amsterdam: North-Holland. Drew, Paul. 1987. Po-faced receipts of teases. Linguistics 25: 219-253. 
Dynel, Marta. 2008. No Aggression, Only Teasing: The Pragmatics of Teasing and Banter. Lodz Papers in Pragmatics 4.2: 241-261.

Dynel, Marta. 2010a. Friend or foe? Chandler's humour from the metarecipient's perspective. In Pragmatic Perspectives on Language and Linguistics 2009. Vol. II: Pragmatics of Semantically Restricted Domains, Iwona Witczak-Plisiecka (ed), 175-205. Newcastle: Cambridge Scholars Publishing.

Dynel, Marta. 2010b. Not hearing things - Hearer/listener categories in polylogues.” MediAzioni 9. http://mediazioni.sitlec.unibo.it, ISSN 19744382 .

Dynel, Marta. 2011a. "You talking to me?" The viewer as ratified listener to film discourse. Journal of Pragmatics 43: 1628-1644.

Dynel, Marta. 2011b. I'll be there for you: On participation-based sitcom humour. In Marta Dynel (ed), The Pragmatics of Humour across Discourse Domains, 311-333. Amsterdam and Philadelphia: John Benjamins.

Dynel, Marta. 2012. Setting our House in order: The workings of impoliteness in multi-party film discourse. Journal of Politeness Research 8: 161-194.

Edwards, Derek. 2000. Extreme case formulations: softeners, investment, and doing nonliteral. Research on Language and Social Interaction 33 (4): $347-373$

Fisher, Aubrey B., Adams, Katherine L., 1994. Interpersonal

Communication. Pragmatics of Human Relationships. New York: McGrawHill.

Fox, Kate. 2004. Watching the English. The Hidden Rules of English Behaviour. London: Hodder.

Goffman, Erving. 1967. Interaction Ritual Essays on Face to Face Behavior. New York: Pantheon.

Goffman, Erving. 1981. Replies and responses. Forms of Talk. 5-77. Philadelphia: University of Philadelphia Press [Originally published as 
Goffman, Erving. 1976. Replies and Responses. Language in Society 5: 257-313].

Greimas, Algirdas, J. 1966. Sémantique structurale. Paris: Larousse. Grice, Herbert Paul. 1975. Logic and conversation. In Studies in Syntax and Semantics III: Speech Acts, Peter Cole and Jerry L. Morgan (eds), 183-98. New York: Academic Press.

Gumperz, John. 1982. Discourse Strategies. Cambridge: Cambridge University Press.

Haugh, Michael. 2010. Jocular mockery, (dis)affiliation and face. Journal of Pragmatics 42: 2106-2119.

Haugh, Michael. 2015. Im/politeness Implicatures. Berlin/Munich/Boston: Walter de Gruyter GmbH.

Haugh, Michael and Bousfield, Derek. 2012. Mock impoliteness, jocular mockery and jocular abuse in Australian and British English. Journal of Pragmatics 44:1099-1114.

Holmes, Janet. 2006. Sharing a laugh: pragmatic aspects of humour and gender in the workplace. Journal of Pragmatics 38: 26-50.

Holmes, Janet and Schnurr, Stephanie 2005. Politeness, humour and gender in the workplace: negotiating norms and identifying contestation. Journal of Pragmatics 1: 121-149.

Joly, André and O'Kelly, Dairine. 1989. Analyse linguistique des textes anglais. Paris: Nathan.

Kisielewska-Krysiuk, Marta. 2010. Banter - a case of phatic communication? In In the Mind and across minds: A relevance-theoretic perspective on communication and translation, Ewa Walaszewska, Marta Kisielewska-Krysiuk and Agnieszka Piskorska (eds), 188-223. Newcastle: Cambridge Scholars Publishing. Kotthoff, Helga. 2007. Oral genres of humour: on the dialectic of genre knowledge and creative authoring. Pragmatics 17: 263-96. 
Lecercle, Jean-Jacques. 1999. Interpretation as Pragmatics. New York: St. Martin's Press.

Leech, Geoffrey. 1983. Principles of Pragmatics. London: Longman.

Leech, Geoffrey. 2014. The Pragmatics of Politeness. New York: Oxford

University Press.

Locher, Miriam A. 2015. Interpersonal pragmatics and its link to (im)politeness research. Journal of Pragmatics 86: 5-10.

Locher, Miriam A. and Bousfield, Derek. (eds), 2008. Impoliteness in language: Studies on its interplay with power in theory and practice. Berlin and New York: Mouton de Gruyter,

Martin, Rod A. 2007. The Psychology of Humor: An Integrative Approach. Burlington MA: Elsevier Academic Press.

Martin, Rod A., Puhlik-Doris, Patricia, Larsen, Gwen, Gray, Jeanette and Weir, Kelly. 2003. Individual differences in uses of humour and their relation to psychological well-being: Development of the Humour Styles Questionnaire. Journal of Research in Personality 37: 48-75.

Mills, Sara. 2003. Gender and Politeness. Cambridge: Cambridge

University Press.

Norrick, Neal. 1993. Conversational Joking. Humour in Everyday Talk.

Bloomington, IN: Indiana University Press.

Norrick, Neal. 2004. Hyperbole, extreme case formulation. Journal of Pragmatics 36 (9): 1727-1739

Nowik, Ewa Karolina. 2005. Politeness of the impolite: Relevance theory, politeness and banter. In Relevance Studies in Poland, Volume 2, Aniela Korzeniowska and Małgorzata Grzegorzewka (eds), 157-166. Warszawa:

The Institute of English Studies, University of Warsaw.

Nowik, Ewa Karolina. 2008. Banter - an Attempt at a Relevance-Theoretic Account. In Relevant Worlds: Current perspectives on Language, Translation and Relevance Theory, Ewa Walaszewska, Marta Kisielewska- 
Krysiuk and Aniela Korzeniowska and Małgorzata Grzegorzewka (eds), 105-118. Newcastle: Cambridge Scholars Publishing.

Plester, Barbara, Sayers, Janet, Grace. 2007. "Taking the piss": Functions of banter in the IT industry. Humor - International Journal of Humor Research 20(2):157-187.

Slugoski, Ben R. and Turnbull, William. 1988. Cruel to be Kind and Kind to be Cruel: Sarcasm, Banter and Social Relations. Journal of Language and Social Psychology 7: 101-121.

Spencer-Oatey, Helen. 2000. Culturally Speaking. London: Continuum. Terkourafi, Marina, 2001. Politeness in Cypriot Greek: A Frame-Based Approach. Ph.D. Dissertation, University of Cambridge.

Terkourafi, Marina, 2008. Toward a unified theory of politeness, impoliteness, and rudeness. In Impoliteness in Language: Studies on its Interplay with Power in Theory and Practice, Derek Bousfield and Miriam Locher (eds), 45-74. Berlin: Mouton de Gruyter. van Dijk, Teun A. and Walter Kintsch. 1983. Strategies of Discourse Comprehension. London and New York: Academic Press. Vergis, Nikos. 2015. The Interplay of Pragmatic Inference, Face and Emotion. Ph.D. dissertation, University of Illinois at Urbana-Champaign.

\footnotetext{
${ }^{\mathrm{i}}$ http://www.theguardian.com/tv-and-radio/2013/jun/04/pointless-alexander-armstrongrichard-osman

ii The analysis draws on several episodes identified as banter by members of the public. The scripts were downloaded from subsaga.com and verified by watching the episodes.

iii http://chambers.co.uk

iv http://www.thetimes.co.uk/tto/education/article4280758.ece http://mikestuchbery.net/2014/11/05/im-banning-banter/

$v$ "the interpellated reader, although subjected as much as subjectified, is not powerless. She sends back the force of interpellation as Perseus's shield, held as a mirror, sent back the Gorgon's gaze and petrified her." (Lecercle 1999: 116)

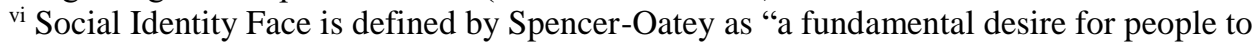
acknowledge and uphold our social identities or roles, e. g., as group leader, valued customer, close friend." (2000: 14)

vii “ a complex array of (non-)verbal acts whereby the speaker somehow diminishes something of relevance to self, other, or a third-party who is not co-present, but does so in a non-serious or jocular frame." (Haugh 2010: 2108)
} 
viii There are other reasons why this sequence may be interpreted as banter, including the hearers' encyclopaedia, a point analysed later in this chapter.

ix $\mathrm{https}: / / \mathrm{www}$. boards.ie//b/thread/2056811805/32?

${ }^{x}$ See for example http://www.bbc.co.uk/programmes/p01pqz2x, series 6, Fishing banter; or http://www.bbc.co.uk/programmes/p013c1b3 series 8, episode 5, Age banter.

xi http://www.dailymail.co.uk/femail/article-2718829/Pointless-Its-turned-lives-upsideAlexander-Armstrong-Richard-Osman-like-catapulted-stardom.html\#ixzz3qeBWx81f

xii Hyperbole can be defined as "overt and blatant exaggeration of some characteristic or property" (Carston and Wearing 2015: 80), while ECFs are a subcategory of hyperbole (Edwards 2000) and "make claims involving end points on scales" (Norrick 2004:1729). xiii Norrick argues that "non-extreme hyperboles are overstated rather than clearly false" (2004: 1735) 